\title{
PENGARUH KOMPONEN RISK-BASED BANK RATING TERHADAP PROFITABILITAS BANK UMUM SYARIAH DI INDONESIA (PERIODE 2011-2014)1)
}

\author{
Bunga Aprigati Iskandar \\ Program Studi S1 Ekonomi Islam-Fakultas Ekonomi dan Bisnis-Universitas Airlangga \\ bungaiskandar@ymail.com \\ Nisful Laila \\ Departemen Ekonomi Syariah-Fakultas Ekonomi dan Bisnis-Universitas Airlangga \\ Email: nisful.laila@gmail.com
}

\begin{abstract}
:
This research aimed to know and analyze the influence of components of Risk-based bank rating method (risk profile, Good Corporate Governance, earnings, and capital) to profitability of Islamic Bank in Indonesia, measured by Return On Assets (ROA). Whereas the ratio used in this research to represent the components of RGEC are risk profile measured by Non Performing Financing (NPF) and Financing to Deposit Ratio (FDR), implementation of GCG by composite score of GCG, earnings by Operational Efficiency Ratio (OER), and capital by Capital Adequacy Ratio (CAR). Sample of this research are 11 Islamic Banks in Indonesia from 2011 to 2014. The analysis techniques used is multiple linear regression.

Based on the analysis result, it can be concluded that NPF, FDR, GCG, OER, and CAR had simultaneous significant effect to ROA. Partially, NPF, FDR, and BOPO have significant effect to ROA. However, CAR and GCG don't affect ROA significantly.
\end{abstract}

Keywords: RGEC, NPF, FDR, OER, CAR, GCG, ROA, Islamic bank profit.

\section{PENDAHULUAN}

Perbankan syariah merupakan salah satu lembaga keuangan syariah yang paling berkembang di Indonesia, dimulai dengan didirikannya Bank Muamalat pada tahun 1992 sebagai bank umum pertama yang beroperasi sesuai dengan prinsip syariah lalu diberlakukannya Undang Undang Nomor 7 Tahun 1992 tentang Perbankan, dimana untuk pertama kalinya di Indonesia, keberadaan bank dengan sistem bagi hasil diatur dalam Undang-undang.

Sebagai lembaga jasa keuangan, bank syariah di Indonesia harus membuat laporan keuangan yang menunjukkan posisi keuangan dan perkembangan bank tersebut dan disajikan kepada pihakpihak yang berkepentingan. Laporan kevangan menyajikan berbagai macam informasi mengenai kondisi keuangan perusahaan, diantaranya profitabilitas, atau kemampuan untuk menghasilkan laba. Laba merupakan gambaran dari kinerja keuangan yang baik, peningkatan laba menunjukkan bahwa adanya peningkatan operasional dari berbagai sumber transaksi (Subramanyan dan Wild, 2014:109).

Dalam Peraturan Bank Indonesia Nomor 13/1/PBI/2011 tentang Penilaian Tingkat Kesehatan Bank Umum disebutkan bahwa seiring dengan perubahan kompleksitas usaha dan profil risiko yang dapat berasal dari bank maupun perusahaan anak bank. Perubahan pendekatan penilaian kondisi bank yang diterapkan secara

1) Jurnal ini merupakan bagian dari skripsi yang ditulis oleh Bunga Aprigati Iskandar; NIM: 041211432001 diuji pada 12 Februari 2016 
Iskandar, et al/Jurnal Ekonomi Syariah Teori dan Terapan Vol. 3 No. 3 Maret 2016:173-186; PENGARUH KOMPONEN RISK-BASED BANK RATING TERHADAP PROFITABILITAS BANK UMUM SYARIAH DI INDONESIA (PERIODE 2011-2014)

internasional mempengaruhi pendekatan penilaian tingkat kesehatan bank. Maka untuk meningkatkan efektivitas penilaian tingkat kesehatan bank diperlukan penyempurnaan penilaian tingkat kesehatan bank dengan pendekatan berdasarkan risiko, atau dikenal dengan sebutan Risk-based Bank Rating. Metode Risk-based Bank Rating mencakup penilaian terhadap empat faktor, yaitu: profil risiko (risk profile), Good Corporate Governance (GCG), rentabilitas (earnings), dan permodalan (capital).

Dengan sistem penilaian yang baru ini, diharapkan bank mampu mengidentifikasi masalah sejak dini, melakukan tindak lanjut perbaikan yang sesuai dan lebih cepat serta menerapkan good corporate governance dan manajemen risiko yang lebih baik (Astutik, 2014).

Namun pada kenyataannya, terlihat kinerja industri perbankan syariah di Indonesia mengalami penurunan, dapat dilihat pada tabel berikut:

Tabel 1.

Rasio Keuangan BUS dan UUS di Indonesia

\begin{tabular}{|l|l|l|l|l|}
\hline & 2011 & 2012 & 2013 & 2014 \\
\hline ROA & $1,79 \%$ & $2,41 \%$ & $2 \%$ & $0,79 \%$ \\
\hline NPF & $2,5 \%$ & $2,2 \%$ & $2,6 \%$ & $4,3 \%$ \\
\hline FDR & $88,9 \%$ & $100 \%$ & $100,3 \%$ & $91 \%$ \\
\hline CAR & $16 \%$ & $14,1 \%$ & $14,4 \%$ & $16 \%$ \\
\hline BOPO & $78 \%$ & $74 \%$ & $78 \%$ & $94 \%$ \\
\hline
\end{tabular}

Sumber: Otoritas Jasa Keuangan, 2015, data diolah.

Dapat di lihat pada tabel di atas, ROA BUS dan UUS di Indonesia mengalami penurunan pada tahun 2014 yang berarti profitabilitas industri perbankan syariah menurun, diikuti dengan peningkatan NPF yang berarti jumlah pembiayaan bermasalah meningkat, FDR yang menurun berarti tingkat likuiditas bank bertambah juga kemampuan bank menyalurkan DPK menurun, diikuti dengan BOPO yang meningkat yang berarti efisiensi kinerja bank syariah menurun.

Dalam penelitian ini digunakan rasio keuangan untuk mengukur kinerja bank umum syariah sesuai dengan empat aspek risk-based bank rating, aspek risk profile diukur dengan NPF, dan FDR; aspek GCG diukur dengan nilai komposit GCG; aspek earnings diukur dengan BOPO; dan aspek capital diukur dengan CAR. Sedangkan profitabilitas bank diukur dengan ROA.

Penelitian sebelumnya dilakukan oleh Astutik (2014), Ponco (2008), Theresia (2013) dan Sabir, dkk (2012) terdapat perbedaan hasil penelitian dari keempat peneliti tersebut. Variabel FDR dan NOM terbukti berpengaruh pada ROA pada keempat penelitian, pada penelitian Sabir, dkk (2012) dan Ponco (2008) variabel BOPO juga memiliki pengaruh negatif signifikan terhadap ROA, sedangkan pada penelitian Theresia (2013) variabel NPL berpengaruh negatif signifikan terhadap ROA.

Dilihat dari hasil penelitian sebelumnya yang berbeda-beda, kinerja profitabilitas Bank Syariah yang menurun, serta penambahan variabel GCG sebagai aspek penilaian yang tidak terdapat dalam CAMEL membuat penulis tertarik untuk melakukan penelitian dengan judul

"Pengaruh Komponen Risk-based Bank 
Iskandar, et al/Jurnal Ekonomi Syariah Teori dan Terapan Vol. 3 No. 3 Maret 2016:173-186; PENGARUH KOMPONEN RISK-BASED BANK RATING TERHADAP PROFITABILITAS BANK UMUM SYARIAH DI INDONESIA (PERIODE 2011-2014)

Rating Terhadap Profitabilitas Bank Umum Syariah di Indonesia (Tahun 2011-2014)".

Rumusan masalah dalam penelitian ini adalah, apakah aspek profil risiko yang dihitung dengan rasio NPF dan FDR, GCG, rentabilitas yang dihitung dengan rasio BOPO, serta permodalan yang dihitung dengan rasio CAR berpengaruh secara parsial dan simultan terhadap profitabilitas Bank Umum Syariah di Indonesia?

Penelitian ini bertujuan untuk mengatahui pengaruh secara parsial dan simultan aspek profil risiko yang dihitung dengan rasio NPF dan FDR, GCG, rentabilitas yang dihitung dengan rasio BOPO, serta permodalan yang dihitung dengan rasio CAR terhadap profitabilitas bank umum syariah di Indonesia.

\section{LANDASAN TEORI}

Peraturan Bank Indonesia No. 6/24/PBI/2004 Tentang Bank Umum menjelaskan bahwa Bank Umum Syariah adalah bank yang melaksanakan kegiatan usaha berdasarkan prinsip syariah yang dalam kegiatannya memberikan jasa dalam lalu lintas pembayaran dengan bentuk hukum yang diizinkan berupa perseroan terbatas. Bank syariah merupakan lembaga intermediasi dan penyedia jasa kevangan yang bekerja berdasarkan etiika dan sistem nilai islam, berprinsip keadilan, dan hanya membiayai kegiatan yang halal (Rivai, dkk, 2007: 759).

Peraturan Bank Indonesia Peraturan Bank Indonesia Nomor 13/1/PBI/2011 tentang Penilaian Tingkat Kesehatan Bank Umum menyebutkan bahwa kesehatan bank merupakan sarana otoritas pengawas dalam menetapkan strategi dan fokus pengawasan terhadap bank. Tingkat kesehatan bank pada dasarnya dinilai melalui pendekatan kualititatif terhadap berbagai aspek yang berpengaruh terhadap kondisi dan perkembangan suatu bank, untuk meningkatkan efektivitas penilaian tingkat kesehatan bank diperlukan penyempurnaan penilaian tingkat kesehatan bank dengan pendekatan berdasarkan risiko, atau riskbased bank rating.

Metode risk-based bank rating terdiri dari empat aspek penilaian yaitu, penilaian terhadap profil risiko, pelaksanaan GCG, rentabilitas, dan permodalan. Dalam penelitian ini tiga dari empat aspek tersebut yaitu profil risiko, rentabilitas, dan permodalan diukur menggunakan rasio kevangan, sedangkan aspek pelaksanaan GCG diukur menggunakan nilai komposit GCG.

Dalam PBI 13/1/PBI/2011 disebutkan bahwa profil risiko bank adalah gambaran mengenai risiko utama yang ada dalam aktivitas bank. Profil risiko merupakan ringkasan yang memberikan gambaran bagi manajemen risiko apa yang perlu mendapatkan perhatian.

Risiko adalah kemungkinan kejadian yang apabila terjadi akan menimbulkan kerugian (Kountur, 2008:6).

Corporate governance merupakan sistem hak, proses, dan kontrol secara keseluruhan yang diterapkan dalam 
Iskandar, et al/Jurnal Ekonomi Syariah Teori dan Terapan Vol. 3 No. 3 Maret 2016:173-186; PENGARUH KOMPONEN RISK-BASED BANK RATING TERHADAP PROFITABILITAS BANK UMUM SYARIAH DI INDONESIA (PERIODE 2011-2014)

internal dan eksternal atas manajemen sebuah entitas bisnis dengan tujuan untuk melindungi kepentingan seluruh stakeholder serta bertindak dengan tanggung jawab sosial dalam segala bidang usaha (Monks dan Minow, 2004:299).

Rentabilitas merupakan kemampuan suatu perusahaan dalam menghasilkan keuntungan. Rentabilitas juga menunjukkan tingkat efektifitas manajemen dalam mengelola perusahaan (Kasmir, 2013:196).

Modal adalah sesuatu yang mewakili kepentingan pemilik dalam satu perusahaan (Arifin, 2005:157). Modal merupakan faktor yang sangat penting bagi perkembangan dan kemajuan bank. Sumber modal sebuah bank dapat dilihat di sisi pasiva laporan posisi kevangan (neraca), yaitu pada rekening modal dan cadangan. Rekening modal merupakan modal yang berasal dari setoran para pemegang saham, sedangkan cadangan merupakan bagian dari keuntungan yang tidak dibagikan kepada pemeagang saham dengan tujuan tertentu, seperti perluasan usaha, dan menjaga likuiditas (Antonio, 2001:248).

Rasio keuangan menurut James $C$ Van Horne (1997), dalam Kasmir (2013:104), adalah indeks yang menghubungkan dua angka akuntansi yang diperoleh dengan membagi satu angka dengan angka lainnya yang bertujuan untuk mengevaluasi kondisi keuangan dan kinerja perusahaan sehingga akan terlihat tingkat kesehatan perusahaan tersebut.

Angka-angka yang digunakan dalam rasio kevangan berasal dari laporan keuangan. Laporan kevangan adalah laporan yang menunjukkan kondisi kevangan perusahaan pada saat ini atau dalam periode tertentu (Kasmir, 2013:7). Rasio keuangan yang digunakan dalam penelitian ini adalah Non Performing Financing (NPF) untuk mengukur risiko pembiayaan, dan Financing to Deposit Ratio (FDR) untuk mengukur risiko likuiditas. Kedua risiko tersebut merupakan yang paling berpengaruh terhadap keuntungan bank (Arifin, 2005:60). Aspek rentabilitas ditinjau dari sumbernya diukur menggunakan rasio Beban Operasional pada Pendapatan Operasional (BOPO). Aspek permodalan ditinjau dari kecukupannya untuk mengantisipasi risiko dan mengembangkan usaha bank menggunakan Capital Adequacy Ratio (CAR). Sedangkan pelaksanaan diukur dengan nilai komposit GCG yang merupakan hasil self-assesment masing masing bank terhadap pelaksanaan GCG nya selama periode tertentu sesuai dengan ketentuan yang sudah ditetapkan Bank Indonesia.

Profitabilitas merupakan kemampuan perusahaan dalam menghasilkan laba (Kasmir, 2013:114). Laba merupakan informasi perusahaan yang paling diminati dalam pasar vang. Laba adalah ringkasan hasil bersih akivitas operasi usaha dalam periode tertentu yang 
Iskandar, et al/Jurnal Ekonomi Syariah Teori dan Terapan Vol. 3 No. 3 Maret 2016:173-186; PENGARUH KOMPONEN RISK-BASED BANK RATING TERHADAP PROFITABILITAS BANK UMUM SYARIAH DI INDONESIA (PERIODE 2011-2014)

dinyatakan dalam istilah keuangan

(Subramanyan dan Wild, 2014:109).

Profitabilitas dalam penelitian ini diukur dengan rasio Return On Assets (ROA), yang merupakan perbandingan antara laba sebelum pajak dengan total aset. Model penelitian yang digunakan dalam penelitian ini digambarkan pada gambar berikut:

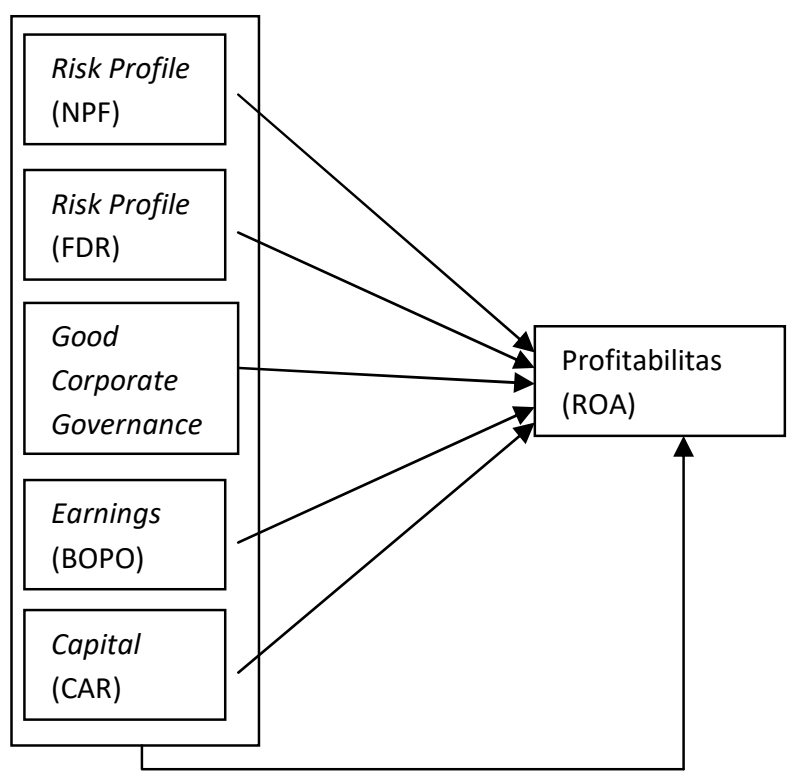

Gambar 1. Model Analisis

Hipotesis dalam penelitian ini yang digunakan dalam penelitian ini adalah: $\mathrm{Hal}_{\mathrm{al}}$ : Variabel Non Performing Financing

(NPF) berpengaruh signifikan terhadap ROA.

Ha2: Variabel Financing to Deposit Ratio (FDR) berpengaruh signifikan terhadap ROA.

Ha3: Variabel Biaya Operasional terhadap

Pendapatan Operasional (BOPO) berpengaruh signifikan terhadap ROA.

$\mathrm{Ha}_{\mathrm{a}}$ : Variabel tidak Capital Adequacy

Ratio (CAR) berpengaruh signifikan terhadap ROA
$\mathrm{H}_{\mathrm{a} 5}$ : Variabel Nilai Komposit GCG

berpengaruh signifikan terhadap ROA. $H_{a 6}$ : Variabel NPF, FDR, BOPO, CAR, GCG secara simultan berpengaruh signifikan terhadap ROA.

\section{METODE PENELITIAN}

Penelitian ini menggunakan pendekatan kuantitatif dengan jenis penelitian merupakan explanation research yang bertujuan untuk menemukan dan menjelaskan hubungan antar variabel yang diteliti (Anshori dan Iswati, 2009:11).

Populasi dalam penelitian ini adalah seluruh Bank Umum Syariah yang terdaftar di Indonesia, proses pemilihan sampel dilakukan dengan purposive sampling dengan kriteria:

1. Bank umum syariah yang mempublikasikan laporan keuangan tahunan (Januari Desember) dan laporan pelaksanaan GCG selama periode penelitian, yaitu tahun 2011 sampai tahun 2014.

2. Bank umum syariah yang memiliki kelengkapan data berdasarkan variabel yang dibutuhkan dalam penelitian.

Dari kriteria tersebut terpilih 11 Bank Umum Syariah yang menjadi sampel dalam penelitian ini, yaitu

Tabel 2.

Sampel Penelitian

\begin{tabular}{|c|l|}
\hline No & \multicolumn{1}{|c|}{ Nama Bank } \\
\hline 1 & PT. Bank Syariah Mandiri \\
\hline 2 & PT. Bank Syariah Muamalat Indonesia \\
\hline 3 & PT. Bank BNI Syariah \\
\hline
\end{tabular}




\begin{tabular}{|c|l|}
\hline 4 & PT. Bank BRI Syariah \\
\hline 5 & PT. Bank Mega Syariah \\
\hline 6 & PT. BCA Syariah \\
\hline 7 & PT. Bank Panin Syariah \\
\hline 8 & PT. Bank Victoria Syariah \\
\hline 9 & PT. Maybank Indonesia Syariah \\
\hline 10 & PT. Bank Syariah Bukopin \\
\hline 11 & PT Bank Jabar Banten Syariah \\
\hline
\end{tabular}

Sumber: Statistik Perbankan Syariah Juni 2015, OJK.

Data yang digunakan berupa data sekunder yang didapat dari laporan keuangan tahunan dan laporan pelaksanaan GCG yang deperoleh dari website masing-masing bank dan website Bank Indonesia.

Definisi operasional dan pengukuran dari variabel-variabel yang digunakan dalam penelitian ini adalah sebagai berikut:

Variabel dependen:

1. ROA merupakan rasio perbandingan laba sebelum pajak terhadap total aset.

Variabel Independen:

1. NPF merupakan rasio perbandingan pembiayaan bermasalah terhadap total pembiayaan.

2. FDR merupakan rasio perbandingan jumlah pembiayaan pada jumlah dana pihak ketiga.

3. BOPO merupakan rasio perbandingan biaya operasional dengan pendapatan operasional.

4. CAR merupakan rasio perbandingan modal dengan aset tertimbang menurut risiko.
5. GCG merupakan nilai komposit berdasarkan hasil self-assesment tiap bank terhadap pelaksanaan GCG nya.

Tabel 3. Definisi Operasional

\begin{tabular}{|c|c|}
\hline \multicolumn{2}{|c|}{ Variabel Independen } \\
\hline Nama Variabel & Definisi Operasional \\
\hline Return On Assets & $\frac{\text { laba sebelum pajak }}{\text { total aset }}$ \\
\hline \multicolumn{2}{|c|}{ Variabel Dependen } \\
\hline Nama Variabel & Definisi Operasional \\
\hline $\begin{array}{ll}\text { Non } & \text { Performing } \\
\text { Financing } & \end{array}$ & $\frac{\text { Pembiayaan Bermasalah }}{\text { Total Pembiayaan }}$ \\
\hline $\begin{array}{l}\text { Financing to Deposit } \\
\text { Ratio }\end{array}$ & $\frac{\text { Total Pembiayaan }}{\text { Total DPK }+ \text { Modal }}$ \\
\hline $\begin{array}{l}\text { Biaya Operasional } \\
\text { terhadap Pendapatan } \\
\text { Operasional }\end{array}$ & $\frac{\text { Biaya Operasional }}{\text { Pendapatan Operasional }}$ \\
\hline $\begin{array}{l}\text { Capital Adequecy } \\
\text { Ratio }\end{array}$ & $\frac{\text { Modal Bank }}{\text { ATMR }}$ \\
\hline Nilai Komposit GCG & $\begin{array}{l}\text { Nilai berdasarkan self- } \\
\text { assesment terhadap } \\
\text { pelaksanaan GCG bank }\end{array}$ \\
\hline
\end{tabular}

Metode analisis yang digunakan adalah analisis linier berganda. Regresi linier berganda digunakan unuk menentukan hubungan sebab-akibat antara satu atau lebih variabel bebas dengan satu variabel terikat. Analisis regresi juga dapat digunakan untuk memprediksi atau meramal (Setiawan, 2015:71). Dalam melakukan analisis regresi linier berganda disyaratkan untuk melakukan uji asumsi klasik agar mendapatkan hasil regresi yang baik.

1. Uji Normalitas

Menurut Ghozali (2009:107) uji normalitas bertujuan untuk menguji apakah dalam model regresi, variabel terikat dan variabel bebas 
keduanya memiliki distribusi normal atau tidak. Model regressi yang baik adalah memiliki distribusi data normal atau mendekati normal. Untuk mendeteksi normalitas dapat dilakukan dengan uji statistik. Tes statistik yang digunakan dalam penelitian ini adalah Kolmogorov Smirnov test.

2. Uji Multikolinearitas

Ghozali (2009:25) menyatakan bahwa uji multikolinearitas bertujuan untuk menguji apakah dalam model regresi ditemukan adanya korelasi yang tinggi atau sempurna antar variabel independen.

Pengujian multikolinieritas dalam penelitian ini dilakukan dengan melihat Variance Inflation Factor (VIF) dan Tolerance (TOL). Sebagai rule of thumb, jika nilai VIF suatu variabel lebih dari 10, maka ada multikolinieritas yang serius pada model regresi.

3. Uji Autokorelasi

Uji auotkorelasi bertujuan menguji apakah model regresi linier ada korelasi antara kesalahan pengganngu pada periode yang bersangkutan dengan kesalahan pengganggu pada periode sebelumnya (Ghozali, 2009:79). Salah satu metode analisis untuk mendeteksi ada tidaknya autokorelasi adalah dengan melakukan pengujian nilai durbin watson (DW test).

4. Uji Heterokedastisitas
Uji ini bertujuan untuk menguji apakah pada model regresi terjadi ketidaksamaan variance dari residual satu pengamatan ke pengamatan lain. Model regresi yang baik adalah homokedastisitas atau tidak terjadi heterokedastisitas. Untuk mendeteksi ada tidaknya heterokedastisitas dalam penelitian ini dilakukan dengan analisis grafik, yaitu melihat grafik scartter plot (Ghazali, 2009:125). Pengujian terhadap hipotesis yang diajukan dilakukan dengan uji signifikansi (pengaruh nyata) variabel independen $(X)$ terhadap variabel dependen $(Y)$ baik secara parsial dengan uji statistik t (t-test) maupun secara simultan dengan menggunakan uji $\mathrm{F}$ (F-test) pada level $5 \%$ $(a=0,05)$.

\section{HASIL DAN PEMBAHASAN}

Hasil penelitian ini meliputi penghitungan komponen risk-based bank rating yaitu profil risiko yang diukur dengan NPF, dan FDR; pelaksanaan GCG yang diukur dengan nilai komposit GCG; rentabilitas yang diukur dengan BOPO; dan permodalan yang diukur dengan CAR. Penghitungan menggunakan data dari laporan keuangan tahunan masing masing bank yang menjadi sampel dalam periode Januari 2011 sampai Desember 2014 sebagai berikut

Tabel 4.

Hasil Analisis Data

\begin{tabular}{|c|c|c|c|c|}
\hline \multirow{2}{*}{ Variabel } & \multicolumn{4}{|c|}{ Rata-rata } \\
\cline { 2 - 5 } & 2011 & 2012 & 2013 & 2014 \\
\hline ROA & 1,95 & 1,71 & 1,26 & 0,68 \\
\hline
\end{tabular}




\begin{tabular}{|c|c|c|c|c|}
\hline NPF & 1,85 & 2,51 & 2,87 & 4,22 \\
\hline FDR & 105,78 & 100,23 & 99,31 & 96,56 \\
\hline GCG & 1,73 & 1,74 & 1,59 & 1,93 \\
\hline BOPO & 84,09 & 80,73 & 84,50 & 93,00 \\
\hline CAR & 31,46 & 23,08 & 19,72 & 21,25 \\
\hline
\end{tabular}

Sumber: hasil pengolahan data sekunder

Tabel 5.

Uji Normalitas

\section{One-Sample Kolmogorov-Smirnov Test}

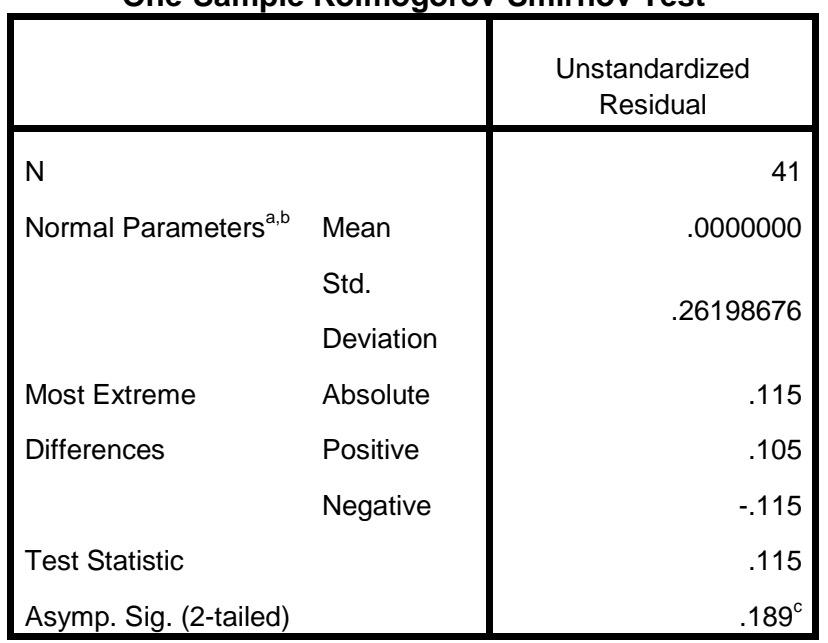

Berdasarkan hasil uji Kolmogorov-Smirnov dapat didapatkan nilai Kolmogorov-

Smirnov adalah 0,115 dan signifikan 0,189.

Dalam hal ini terbukti bahwa data terdistribusi secara normal karena nilai sigifikan lebih besar dari 0,05.

Tabel 6.

Uji Multikolinearitas

\begin{tabular}{|l|l|l|}
\hline \multirow{2}{*}{ Model } & \multicolumn{2}{|l|}{ Collinearity Statistics } \\
\cline { 2 - 3 } & Tolerance & VIF \\
\hline NPF & 0,527 & 1,899 \\
\hline FDR & 0,594 & 1,683 \\
\hline GCG & 0,684 & 1,461 \\
\hline BOPO & 0,483 & 2,072 \\
\hline CAR & 0,471 & 2,123 \\
\hline
\end{tabular}

Berdasarkan nilai VIF yang dibawah 10 dan nilai Tolerance dibawah satu menunjukkan bahwa tidak ada masalah multikolinearitas antar variabel independen.

Tabel 7. Uji Durbin-Watson

\begin{tabular}{|l|c|r|r|r|r|}
\hline Model & $\mathrm{R}$ & $\begin{array}{c}\mathrm{R} \\
\text { Square }\end{array}$ & $\begin{array}{c}\text { Adjusted } \\
\text { R Square }\end{array}$ & $\begin{array}{c}\text { Std. Error of } \\
\text { the Estimate }\end{array}$ & $\begin{array}{c}\text { Durbi } \\
\text { Wats } \\
\text { on }\end{array}$ \\
\hline 1 & $.768^{\mathrm{a}}$ & .590 & .531 & .28008 & 2.288 \\
\hline
\end{tabular}

Berdasarkan hasil uji Durbin Watson, nilai Durbin Watson berada di area no decision, yaitu $4-d u<d<4-d l$. Sehingga untuk mendapatkan hasil yang lebih meyakinkan, penulis melakukan uji autokorelasi dengan run test.

Tabel 8.

Runs Test

\begin{tabular}{|l|r|}
\hline & $\begin{array}{c}\text { Unstandardized } \\
\text { Residual }\end{array}$ \\
\hline Test Value $^{\mathrm{a}}$ & .03326 \\
Cases < Test Value & 20 \\
Cases >= Test Value & 21 \\
Total Cases & 41 \\
Number of Runs & 22 \\
Z & .004 \\
Asymp. Sig. (2-tailed) & .997 \\
\hline
\end{tabular}

Berdasarkan hasil runs test, didapatkan nilai signifikan sebesar 0,997 yang menunjukkan bahwa tidak terdapat autokorelasi karena nilai signifikan lebih besar dari 0,05. 


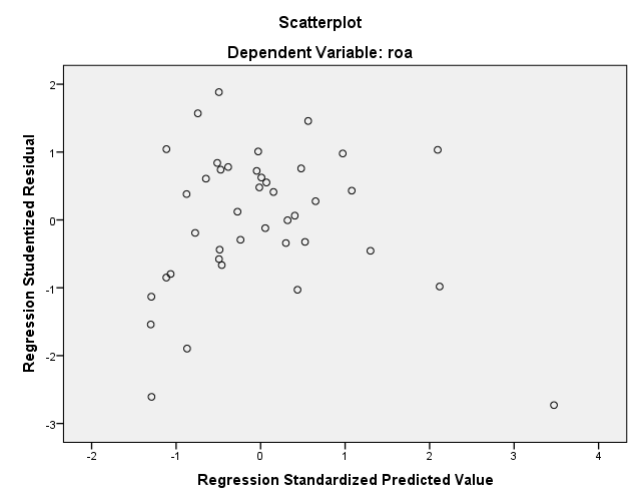

Gambar 2.

\section{Scatter Plot}

Dapat dilihat pada gambar 2 titik-titik menyebar menyebar secara acak, serta tersebar baik di atas maupun di bawah angka 0 pada sumbu Y. Maka dapat diambil kesimpulan bahwa tidak terdapat gejala heteroskedastisitas pada model transformasi regresi yang digunakan.

Tabel 9.

Koefisien Variabel

\begin{tabular}{|l|l|}
\hline Variabel & Koefisien B \\
\hline Konstanta & 12,641 \\
\hline NPF & $-1,647$ \\
\hline FDR & 0,297 \\
\hline BOPO & $-5,210$ \\
\hline GCG & $-0,841$ \\
\hline CAR & 0,565 \\
\hline
\end{tabular}

Dari tabel 9 dapat dirumuskan persamaan model penelitian ini adalah:

$$
\begin{aligned}
\mathrm{ROA}= & 12,641-1,647 \text { (NPF) +0,297 (FDR) - } \\
& 5,210(\mathrm{BOPO})-0,841 \text { (GCG) +0,565 } \\
& (\mathrm{CAR})
\end{aligned}
$$

Tabel 10.

Uji F

ANOVA $^{\mathrm{a}}$

\begin{tabular}{|l|r|r|r|r|r|}
\hline Model & $\begin{array}{c}\text { Sum of } \\
\text { Squares }\end{array}$ & Df & $\begin{array}{c}\text { Mean } \\
\text { Squar } \\
\text { e }\end{array}$ & F & Sig. \\
\hline 1 Regression & 3.950 & 5 & .790 & 10.072 & $.000^{\mathrm{b}}$ \\
& 2.745 & 35 & .078 & & \\
$\quad$ Residual & 6.696 & 40 & & & \\
$\quad$ Total & &
\end{tabular}

a. Dependent Variable: roa

b. Predictors: (Constant), car, gcg, npf, fdr, bopo

Berdasarkan hasil Uji $F$ didapatkan nilai $F$ hitung sebesar 10,072, nilai tersebut lebih besar dari $F$ tabelnya yaitu 2,49. Maka dapat diputuskan bahwa Ho ditolak, diperkuat dengan nilai signifikannya sebesar 0,000 jauh dibawah 0,05. Dapat disimpulkan bahwa variabel NPF, FDR, GCG, BOPO, dan CAR secara simultan berpengaruh signifikan terhadap ROA.

Tabel 11.

Koefisien Determinasi

\begin{tabular}{|l|r|r|r|r|r|}
\hline Model & $\mathrm{R}$ & $\begin{array}{c}\mathrm{R} \\
\text { Square }\end{array}$ & $\begin{array}{c}\text { Adjusted R } \\
\text { Square }\end{array}$ & $\begin{array}{c}\text { Std. Error } \\
\text { of the } \\
\text { Estimate }\end{array}$ & $\begin{array}{c}\text { Durbin- } \\
\text { Watson }\end{array}$ \\
\hline 1 & $.768^{\mathrm{a}}$ & .590 & .531 & .28008 & 2.288 \\
\hline
\end{tabular}

Nilai R square sebesar 0,590 memiliki arti bahwa persamaan model penelitian mampu menjelaskan variabel dependen sebesar 59\%, sedangkan $49 \%$ sisanya dijelaskan oleh variabel lain yang tidak dibahas dalam penelitian ini. 
Iskandar, et al/Jurnal Ekonomi Syariah Teori dan Terapan Vol. 3 No. 3 Maret 2016:173-186; PENGARUH KOMPONEN RISK-BASED BANK RATING TERHADAP PROFITABILITAS BANK UMUM SYARIAH DI INDONESIA (PERIODE 2011-2014)

Tabel 12.

Uji

Coefficients $^{a}$

\begin{tabular}{|c|c|c|c|c|c|}
\hline \multirow[b]{2}{*}{ Model } & \multicolumn{2}{|c|}{$\begin{array}{c}\text { Unstandardized } \\
\text { Coefficients }\end{array}$} & \multirow{2}{*}{$\begin{array}{c}\text { Standardized } \\
\text { Coefficients } \\
\text { Beta }\end{array}$} & \multirow[b]{2}{*}{$t$} & \multirow[b]{2}{*}{ Sig. } \\
\hline & B & $\begin{array}{l}\text { Std. } \\
\text { Error }\end{array}$ & & & \\
\hline 1 (Constant) & 12.641 & 2.612 & & 4.839 & .000 \\
\hline $\mathrm{Npf}$ & -1.647 & .562 & -.412 & -2.932 & .006 \\
\hline Fdr & .297 & .123 & .360 & 2.411 & .021 \\
\hline Bopo & -5.210 & .951 & -.853 & -5.478 & .000 \\
\hline Gcg & -.841 & .554 & -.199 & -1.519 & .138 \\
\hline Car & .565 & .288 & .310 & 1.965 & .057 \\
\hline
\end{tabular}

a. Dependent Variable: roa

Setelah membandingkan $\dagger$ tabel dan $\dagger$ hitung serta melihat nilai signifikannya dapat disimpulkan bahwa variabel NPF, FDR, dan BOPO berpengaruh secara parsial dan signifikan terhadap ROA. Sedangkan variabel GCG dan CAR secara parsial berpengaruh tidak ssignifikan terhadap ROA.

\section{Pembahasan}

Hasil analisis uji $\dagger$ menunjukkan bahwa NPF dengan t-stat sebesar -2,932 dan tingkat signifikan 0,006 memiliki pengaruh negatif signifikan terhadap ROA. Hasil tersebut membuktikan teori yang sudah ada yaitu semakin rendah pembiayaan bermasalah yang ditanggung bank, maka profitabilitas bank akan meningkat (NPF sebagai indikator pembiayaan bermasalah dan ROA sebagai indikator profitabilitas).

Hasil penelitian ini sesuai dengan hasil penelitian Theresia (2013) yang menyimpulkan bahwa NPF berpengaruh terhadap ROA. Hal ini semakin menguatkan teori yang ada bahwa faktor pembiayaan bermasalah memiliki pengaruh yang kuat terhadap laba yang diperoleh bank. Apabila suatu bank mempunyai Non Performing Financing (NPF) yang tinggi, maka akan memperbesar biaya baik biaya pencadangan aktiva produktif maupun biaya lainnya, sehingga berpengaruh terhadap kinerja bank, tingginya NPF juga menyebabkan menurunnya pendapatan dan berakibat pada turunnya laba yang dihasilkan (Ali, 2004:152).

Berdasarkan hasil analisis regresi, NPF berpengaruh negatif signifikan terhadap ROA dengan koefisien sebesar -1,647 artinya peningkatan variabel NPF sebesar satu satuan akan menurunkan ROA sebesar 1,647 satuan.

Hasil analisis uji † menunjukkan bahwa FDR dengan t-stat sebesar 2,411 dan tingkat signifikan 0,021 memiliki pengaruh positif signifikan terhadap ROA. Hasil tersebut membuktikan teori yang sudah ada yaitu semakin tinggi kemampuan bank dalam menyalurkan dananya maka semakin tinggi laba yang akan diperoleh. Sebaliknya, jika bank memiliki kelebihan likuiditas yang menganggur akan berdampak pada pendapatan bank yang berkurang karena tingginya biaya pemeliharaan kas yang menganggur (FDR sebagai indikator likuiditas) (Ponco, 2008). Hasil penelitian ini sesuai dengan hasil penelitian Astutik (2014), Ponco (2008), Sabir (2012), dan Theresia (2013) yang 
Iskandar, et al/Jurnal Ekonomi Syariah Teori dan Terapan Vol. 3 No. 3 Maret 2016:173-186; PENGARUH KOMPONEN RISK-BASED BANK RATING TERHADAP PROFITABILITAS BANK UMUM SYARIAH DI INDONESIA (PERIODE 2011-2014)

menyimpulkan bahwa FDR berpengaruh terhadap ROA. Hal ini semakin menguatkan teori yang ada bahwa faktor likuiditas memiliki pengaruh yang kuat terhadap laba yang diperoleh bank.

Berdasarkan hasil analisis regresi, FDR berpengaruh positif signifikan terhadap ROA dengan koefisien sebesar 0,297 artinya peningkatan variabel FDR sebesar satu satuan akan meningkatkan ROA sebesar 0,297 satuan.

Hasil anaisis uji $\dagger$ menunjukkan bahwa GCG dengan t-stat -1,519 dan tingkat signifikan 0,138 memiliki pengaruh negatif yang tidak signifikan terhadap ROA. Hasil tersebut berbeda dengan teori yang sudah ada bahwa semakin baik pelaksanaan GCG sebuah bank, maka akan sebaik kinerja manajemen bank tersebut dalam memperoleh laba (Witjaksono dan Nathalia, 2014). Hasil ini berbeda dengan hasil penelitian Theresia (2013) yang menyimpulkan bahwa GCG berpengaruh signifikan terhadap ROA.

Pengukuran GCG di Indonesia yang merupakan suatu penilaian non financial dan kualitatif belum mampu dijadikan tolak ukur investor atau nasabah di Indonesia. Sedangkan menurut Sulaiman (2012) dalam Astutik (2014) mekanisme GCG lebih mempengaruhi profitabilitas perusahaan di Indonesia berupa tingkat pengembalian ekuitas yang diukur dengan ROE. Sedangkan pengukuran mekanisme GCG terhadap ROA secara individual tidak berpengaruh. Hasil ini dapat diartikan bahwa faktor GCG tidak cukup memberikan pengaruh pada return bank tanpa ada faktor lain. Hal tersebut menunjukkan bahwa tinggi atau rendahnya kualitas pelaksanaan GCG suatu bank tidak terlalu berpengaruh pada laba yang diperoleh bank tersebut. Hasil penelitian ini mendukung penelitian Astutik (2014).

Hasil analisis uji $\dagger$ menunjukkan bahwa BOPO dengan t-stat sebesar $-5,365$ dan tingkat signifikan 0,000 memiliki pengaruh negatif signifikan terhadap ROA. Hasil tersebut membuktikan teori yang sudah ada yaitu semakin efisien bank dalam mengelola dana operasionalnya maka akan semakin tinggi laba yang diperoleh (BOPO sebagai indikator efisiensi).

Hasil penelitian ini sesuai dengan hasil penelitian Ponco (2008) yang menyimpulkan bahwa BOPO berpengaruh terhadap ROA. Hal ini semakin menguatkan teori yang ada bahwa faktor efisiensi memiliki pengaruh yang kuat terhadap profitabilitas bank. Rasio BOPO yang semakin meningkat mencerminkan kurangnya kemampuan bank dalam menekan biaya operasionalnya yang dapat menimbulkan kerugian karena bank kurang efisien dalam mengelola usahanya (BI, 2004). Berdasarkan hasil analisis regresi, BOPO berpengaruh negatif signifikan terhadap ROA dengan koefisien sebesar $-5,317$ artinya peningkatan variabel BOPO sebesar satu satuan akan menurunkan ROA sebesar 5,317 satuan. 
Iskandar, et al/Jurnal Ekonomi Syariah Teori dan Terapan Vol. 3 No. 3 Maret 2016:173-186; PENGARUH KOMPONEN RISK-BASED BANK RATING TERHADAP PROFITABILITAS BANK UMUM SYARIAH DI INDONESIA (PERIODE 2011-2014)

Hasil analisis uji † menunjukkan bahwa CAR dengan t-stat sebesar 1,965 dan tingkat signifikan 0,057 memiliki pengaruh positif dan tidak signifikan terhadap ROA. Hasil tersebut berbeda dengan teori yang sudah ada bahwa semakin kuat permodalan suatu bank, maka akan semakin tinggi kemungkinan bank tersebut untuk mendapat keuntungan yang lebih besar (CAR sebagai indikator permodalan).

Hal ini dikarenakan modal yang dimiliki bank hanya digunakan sebagai ketentuan dari BI. Ketentuan besarnya minimum CAR $8 \%$ hanya dimaksudkan Bank Indonesia untuk menyeseuaikan kondisi dengan perbankan internasional. Bank syariah juga dianggap belum optimal dalam menyalurkan pembiayaan kepada debitur. Hal ini dapat dilihat pada tingkat CAR Bank Victoria Syariah pada tahun 2011 sebesar 45,2\% sedangkan FDR nya hanya $46,08 \%$. Padahal semakin tinggi CAR menunjukkan bahwa bank memiliki kecukupan modal yang tinggi untuk menangani risiko-risiko yang dapat timbul. Seharusnya, jika sebuah bank memiliki tingkat CAR yang tinggi, bank tersebut dapat menyalurkan dana yang lebih banyak juga sehingga akan menghasilkan pendapatan yang lebih tinggi. Hal tersebut menunjukkan, tinggi rendahnya permodalan yang dimiliki bank tidak terlalu berpengaruh terhadap kegiatan pembiayaan bank, yang merupakan kegiatan operasional utama bank dalam menghasilkan pendapatan.
Hasil penelitian ini sesuai dengan hasil penelitian Astutik (2014) yang menyimpulkan bahwa CAR memiliki pengaruh yang tidak signifikan terhadap ROA.

Hasil analisis uji $F$ menunjukkan bahwa seluruh variabel yaitu NPF, FDR, GCG, $B O P O$, dan CAR dengan $F$ hitung sebesar 10, 072 dan tingkat signifikan 0,000 memiliki pengaruh secara signifikan secara simultan terhadap ROA. Hasil ini sesuai dengan penelitian Theresia (2013) dan Astutik (2014).

Variabel-variabel dependen dalam penelitian ini digunakan untuk menggambarkan aspek aspek dalam penilaian tingkat kesehatan metode RGEC, yang terdiri dari profil risiko yang diukur dengan NPF dan FDR, pelaksanaan GCG yang diukur dengan nilai komposit GCG, rentabilitas yang diukur dengan BOPO, dan permodalan yang diukur dengan CAR. Hasil penelitian menunjukkan bahwa tingkat performa kinerja bank berpengaruh terhadap profitabilitas bank. Semakin baik kinerja bank dari sisi penanganan risiko, pelaksanaan GCG, rentabilitas, dan permodalan, akan meningkatkan profitabilitas sehingga laba yang dihasilkan semakin tinggi.

\section{SIMPULAN}

Berdasarkan hasil analisis dan pembahasan pada bab sebelumnya, maka dapat ditarik kesimpulan sebagai berikut: 
1. Seluruh variabel yang digunakan untuk mengukur keempat aspek penilaian tingkat kesehatan bank dengan metode risk-based bank rating, yaitu NPF, FDR, nilai komposit GCG, BOPO, dan CAR secara simultan berpengaruh signifikan terhadap profitabilitas bank umum syariah. Hal tersebut ditunjukan dengan nilai signifikan sebesar 0,000 lebih kecil dari a=0,05. Dapat disimpulkan bahwa performa kinerja pengelolaan usaha berpengaruh pada profitabilitas bank umum syariah.

2. Berdasarkan hasil uji signifikan t, diperoleh kesimpulan bahwa variabel NPF, FDR, dan BOPO berpengaruh signifikan secara parsial terhadap ROA. Sedangkan variabel GCG dan CAR tidak berpengaruh signifikan terhadap ROA.

3. Pengaruh variabel NPF, FDR, nilai komposit GCG, BOPO, dan CAR terhadap ROA sebesar 59\%.

4. Variabel BOPO mempunyai pengaruh paling dominan terhadap ROA bank umum syariah diantara keempat variabel lain. Hal tersebut ditunjukkan dengan besarnya koefisien regresi variabel sebesar 5,317 .

\section{DAFTAR PUSTAKA}

Ali, Masyhud. 2004. Asset Liability Management : Menyiasati Risiko Pasar dan Risiko Operasional. PT.Gramedia Jakarta.

Anshori, Muchlish dan Iswati, Sri. 2009. Buku Ajar Metodologi Penelitian Kuantitatif. Surabaya: Airlangga University Press.

Antonio, M. Syafii. 2001. Bank Syariah: dari Teori ke Praktek. Jakarta: Gema Insani.

Arifin, Zainul. 2005. Dasar-dasar Manajemen Bank Syariah. Yogyakarta: Pustaka Alvabet.

Astutik, Puji. 2014. Pengaruh Tingkat Kesehatan Bank Menurut Risk-based Bank Rating terhadap Kinerja Keuangan IStudi pada Bank Umum Syariah di Indonesia). Skripsi Sarjana Ekonomi Universitas Brawijaya.

Bank Indonesia. 2004. Peraturan Bank Indonesia Nomor 6/10/PBI/2004 Tentang Penilaian Tingkat Kesehatan Bank Umum. Jakarta. . 2007. Surat Edaran Bank Indonesia Nomor 9/12/DPNP Tentang Pelaksanaan Good Corporate Governance bagi Bank Umum. Jakarta 2007. Surat Edaran Bank Indonesia No. 9/24/DPbS Tentang Sistem Penilaian Tingkat Kesehatan Bank Umum Berdasarkan Prinsip Syariah. Jakarta.

2011. Peraturan Bank Indonesia Nomor 13/1/PBI/2011 Tentang Penilaian Tingkat Kesehatan Bank Umum. Jakarta. 
Iskandar, et al/Jurnal Ekonomi Syariah Teori dan Terapan Vol. 3 No. 3 Maret 2016:173-186; PENGARUH KOMPONEN RISK-BASED BANK RATING TERHADAP PROFITABILITAS BANK UMUM SYARIAH DI INDONESIA (PERIODE 2011-2014)

Ghozali, Imam. 2009. Ekonometrika Teori, Konsep, dan Aplikasi dengan SPSS 17. Semarang: Badan Penerbit Universitas Diponegoro.

Kasmir. 2013. Analisis Laporan Keuangan. Jakarta: Raja Grafindo Persada.

Kountur, Ronny. 2008. Mudah Memahami Manajemen Risiko Perusahaan. Jakarta: Pernerbit PPM.

Monks, Robert A. G. and Minow, Nell. 2004. Corporate Governance. Oxford: Backwell Publishing.

Otoritas Jasa Keuangan. 2014. Peraturan OJK Nomor 8/POJK.03/2014 tentang Penilaian Tingkat Kesehatan Bank Umum Syariah dan Unit Usaha Syariah. Jakarta.

2014. Surat Edaran OJK

Nomor 10/SEOJK.03/2014 Tentang Penilaian Tingkat Kesehatan Bank Umum Syariah Dan Unit Usaha Syariah. Jakarta.

2015. Statistik

Perbankan Syariah Juni 2015. Jakarta.

Perwataatmadja, Karnaen A. dan Tanjung, Hendri. 201 1. Bank Syariah (Teori, Praktik, dan Peranannya). Jakarta: Celestial Publishing.

Ponco, Budi. 2008. Analisis Pengaruh CAR, NPL, BOPO, NIM dan LDR Terhadap ROA (Studi Kasus Pada Perusahaan Perbankan yang Terdaftar di Bursa Efek Indonesia Periode 2004-2007). Tesis Master Manajemen Universitas Diponegoro Semarang.
Republik Indonesia. 1992. Undang undang Nomor 7 Tahun 1992 Tentang Perbankan. Sekretariat Negara. Jakarta. 1998. Undang undang Nomor 10 Tahun 1998 Tentang Perubahan Atas Undang undang Nomor 7 Tahun 1992 Tentang Perbankan. Sekretariat Negara. Jakarta. Rivai, Veithzal, dkk. 2007. Bank and Financial Institution Management. Jakarta: RajaGrafindo Pustaka.

Sabir, M., dkk. 2012. Pengaruh Rasio Kesehatan Bank Terhadap Kinerja Keuangan Bank Umum Syariah dan Bank Konvensional di Indonesia. Jurnal Analisis, Juni 2012, Vol.1 No.1. h 79-86.

Setiawan, Budi. 2015. Teknik Praktis Analisis Data Penelitian Sosial dan Bisnis dengan SPSS. Yogyakarta: ANDI.

Subramanyan, K. R. and Wild, John J. Analisis Laporan Keuangan. Terjemahan oleh Dewi Yanti. 2014. Jakarta: Salemba Empat.

Theresia, Debby. 2013. Pengaruh NPL, LDR, CAR, NIM, dan GCG terhadap ROA (Studi pada Bank yang terdaftar di BEI periode 2004-2012). Skripsi Sarjana Ekonomi Universitas Diponegoro.

Witjaksono, Armanto dan Nathalia, Monica. 2014. Pengaruh Tingkat Kesehatan Bank Berdasarkan Metode RGEC Terhadap Return Saham pada Perusahaan Perbankan Go Public di Indonesia Stock Exchange (IDX) Tahun 2011-2012, Jurnal GICI Vol. 4 No. 3. 